\title{
Foreign banks
}

\section{in Latin America: \\ a paradoxical result}

\author{
Graciela Moguillansky, Rogerio Studart and \\ Sebastián Vergara
}

Graciela Moguillansky

Investment and Corporate

Strategies Unit, ECLAC

- gmoguillansky@eclac.cl

Rogerio Studart

Financial Specialist,

Sustainable Development

Department,

Inter-American Development Bank

(IDB).

This paper was produced while this

author was an Economic Affairs

Officer in the ECLAC Economic

Development Division

•rogerios@iadb.org

Sebastián Vergara

Consultant, Investment and

Corporate Strategies Unit, ECLAC

- severgara@eclac.cl

$\mathrm{D}$

uring the 1990s there was a dramatic increase in the presence of foreign banking in Latin America. Macroeconomic stability and economic reforms, especially capital market and financial liberalization, created attractive conditions for banks which were looking for economies of scale and worldwide growth. At the same time governments hoped that foreign bank penetration would provide a solution to the need to increase capital within the system, as well as representing an insurance against systemic risk. The efforts to attract foreign investment coincided with the strategy of the leading players to become global banks. Now that the initial penetration has been achieved, it is worth analyzing what the impacts have been on the performance of the financial system. The main conclusion is that there has been a positive outcome for the region in terms of microeconomic efficiency, but this contrasts with the macroeconomic impact. 


\section{I \\ Structural characteristics and problems of banking systems prior to the 1990s}

For the purpose of this analysis, attention needs to be drawn to four basic characteristics of the Latin American financial system, which have been present throughout its history and in some cases still persist today. The first is that the region's banks have predominantly focused on traditional commercial-banking activities, while the securities market remained very poorly developed, and was in fact non-existent in many countries. Secondly, despite the systemic importance of banks, the volume of lending in relation to Gross Domestic Product (GDP) was and remains very small. Thirdly, the State has traditionally played a major role in the financial sector, and this has been associated (albeit without proven causality) with a concentration of private-sector banking activity in the short-term credit segment. Public-sector financing institutions have tended to specialize in long-term funding, generally linked to the national development plans that were commonplace until the 1970s. Lastly, the region's banking systems have always been characterized by their shallowness and narrow coverage. ${ }^{1}$ This has meant that a significant fraction of firms and families have little or no access to credit, and that private financing is characterized by large spreads, and hence high interest rates on loans, with very short maturities.

Government policy to attract foreign banks stemmed directly from the need to resolve these structural problems in the banking sector. So-called "firstgeneration" financial reforms (table 1 and box 1) were an attempt to increase sectoral competitiveness and improve efficiency by liberalizing its operations and reducing State intervention, both directly (downsizing of the public financial sector) and indirectly (lower reserve requirements, together with deregulation of interest rates and directed credit mechanisms).

The structural reforms created a new macroeconomic environment, which in turn had effects on the way banks operated. In many cases, this interaction between the performance of the banking system and the new macroeconomic climate generated tensions or banking crises that had two broad consequences: firstly, the introduction of a new wave of (second generation) reforms aimed at strengthening the institutional framework (through new regulation and supervision); and secondly, the adoption of an explicit policy to attract international banks, which led to privatization and acquisition processes.

TABLE 1

Latin America: First-generation reforms of the financial system

\begin{tabular}{|c|c|c|c|c|c|c|}
\hline \multirow[t]{2}{*}{ Country } & \multirow{2}{*}{$\begin{array}{c}\text { Liberalization } \\
\text { of interest rates }\end{array}$} & \multirow{2}{*}{$\begin{array}{l}\text { Start of an intensive } \\
\text { period of privatization }\end{array}$} & \multirow{2}{*}{$\begin{array}{l}\text { Adoption of capital } \\
\text { adequacy requirements }\end{array}$} & \multicolumn{2}{|c|}{ Bank reserves $(\%)$} & \multirow{2}{*}{$\begin{array}{c}\text { Tension (1) } \\
\text { or systemic crises } \\
\text { following reform (2) }\end{array}$} \\
\hline & & & & 1990 & 2000 & \\
\hline Argentina & 1989 & 1995 & 1991 & 24 & 4 & $1995(2)$ \\
\hline Bolivia & 1985 & 1992 & 1995 & 25 & 9 & $1985(1)$ \\
\hline Brazil & 1989 & 1997 & 1995 & 15 & 12 & 1994 (1) \\
\hline Chile & $1974^{\mathrm{a}}$ & 1974-1987 & 1989 & 6 & 5 & 1982(2) \\
\hline Colombia & 1979 & 1993 & 1992 & 38 & 8 & 1998(2) \\
\hline Costa Rica & 1995 & 1984 & 1995 & 43 & 18 & 1994(1) \\
\hline Mexico & 1988 & 1992 & 1994 & 5 & 7 & 1994(2) \\
\hline Paraguay & 1990 & 1984 & 1991 & 33 & 26 & 1995(1) \\
\hline Peru & 1991 & 1993 & 1993 & 31 & 26 & 1995(1) \\
\hline Uruguay & 1974 & 1974 & 1992 & 45 & 22 & 1982(2) \\
\hline Venezuela & 1989 & 1996 & 1993 & 18 & 29 & 1994(2) \\
\hline
\end{tabular}

Source: Prepared by the authors, on the basis of ECLAC (1995 and 1996).

a The banks were intervened between 1982 and 1984; the system was reliberalized starting in 1985.

1 This refers to the proportion of enterprises and families with access to credit. 
Box 1

FIRST - AND SECOND- GENERATION FINANCIAL REFORMS IN LATIN AMERICA

The financial reforms introduced in Latin America during the last two decades differed from country to country, not only in terms of when the reforms were implemented but also in their intensity and scope. To simplify the analysis, however, they can be divided into two phases, in some cases overlapping in time: the first phase, which can be described as first-generation reforms, entailed dismantling State controls on the returns to financial assets (especially interest rates), on the allocation of financial resources, and on the entry of agents into the system (lowering of entry barriers). All of this was accompanied by financial opening to the exterior. In terms of regulatory reform, this phase also included the adoption of capital requirements in compliance with the Basel Accord of 1988. As shown in table 1, this process took place between 1985 and 1995 in many countries, and it was often followed by economic crises, frequently stemming from the exponential growth of bank lending that had occurred earlier.

Given the problems of stability that emerged from the mid-1990s onwards, many countries began to implement second-generation reforms aimed at enhancing regulatory and supervisory mechanisms, in order to make their domestic banking systems sounder. These reforms were particularly intensive following the "tequila crisis", which in many countries had destabilized the financial system and in others had triggered an outright banking crisis. This second wave of reforms, particularly those implemented following the Basel Accord, required banks to maintain a level of capital that was adequate in relation to the risk attached to their banking assets; to evaluate and rate their loan portfolios more carefully according to the structure of those risks; and to provide more transparent information to the supervisory bodies.

The pace and depth of regulatory and supervisory reform in each country were directly related to the strength of the effect of the "tequila crisis" on the banking sector in question, and the desire of the domestic authorities to rapidly restore "business as usual" in institutions and markets. For example, while regulatory adjustments were minimal in Chile during the second half of the 1990s, far-reaching changes were made in Argentina, Brazil and Mexico. In most of the countries hit by the crisis, reform began with a restructuring of the domestic banking sector; this process was accompanied by State guarantees, and usually included an injection of liquidity into the system, all of which facilitated bank mergers and acquisitions. In this process, giving incentives for foreign banks to enter the market became an overt policy. The State guarantees extended to the financial system were generally accompanied by requirements relating to deposit insurance, capital requirements and greater liquidity.

The financial reforms of the 1990s overtly encouraged the entry of foreign banks. First-generation reforms had allowed banks to operate in markets that had previously been off-limits - providing services such as factoring and leasing, for example- and had also facilitated stock-market operations, particularly brokerage, underwriting and pension-fund management. As we shall see below, these additional freedoms and broader scope of action were fundamental for the operations of international banks, particularly as their strategy had now shifted towards universalization. In their attempt to grant equivalent legal status to all nations, second-generation reforms created a regulatory and supervisory environment similar to that prevailing in developed economies, thereby opening the doors to foreign banks. In this respect, the two generations of reforms complemented each other to create a climate more suited to the expansion strategies of international banks.

Source: Prepared by the authors on the basis of Stallings and Studart (2001). 
1. Financial market liberalization, crisis and restructuring: from the "tequila crisis" to 1997

An essential background for understanding the current development of the Latin American banking system is the financial liberalization that took place between the 1980s and 1990s, both locally and internationally. Chile was an exception to this, however, having begun the process a decade earlier than the other countries in the region. Starting from a system in which State authorities set interest rates, directed credit and required a high proportion of bank deposits to be held as reserve requirements, commercial banks were now given freedom to decide where and how much to lend, and at what price. More or less at the same time, capital-market liberalization enabled local banks to borrow in foreign currency, and allowed foreign banks to operate in the local market. Frequently, these changes were implemented without an adequate system of bank regulation and supervision in place, which in several instances led to problems in regional banks whose executives had little or no experience in analyzing local credit, let alone the international market.

The initial financial deregulation also affected business goals. Existing institutions could now engage in new activities and become "universal banks". This allowed them to operate in securities and insurance markets, provide asset-management services, and hold equity positions in non-financial firms. To some extent, this process mirrored what was happening in the industrialized countries, but with the difference that the securities market in the region remained very underdeveloped. Accordingly, despite greater diversification, bank portfolios were restricted to short-term securities dealing, insurance products and real-estate activities.

Financial opening and deregulation did not yield the expected results, however. Instead, they provoked credit booms, mismatches between currencies and maturities, and ultimately banking crises. As had happened in Chile during the external debt crisis, then in Mexico in 1994, East Asia in 1998 and Argentina in 2001, mistakes made by local actors themselves were reason enough for crisis, but when compounded by external shocks, the situation became much more serious (Held and Jiménez, 2001). By the mid-1990s, banking crises had become a new feature of Latin America's financial systems, and bank bailouts by government had become commonplace. Initially, salvage operations were limited to non-recoverable port- folios, but this was later followed by bank recapitalization, then liquidation, or mergers and acquisitions by foreign banks. Subsequently, in order to avert future crises, banking regulation and supervision were introduced, greater information and transparency were required, and in some cases deposit insurance was put in place. As a result of these crises, the initial expectations of financial reform changed: financial liberalization was and remains a condition for long-term market development, but the latter cannot be achieved without stability in the system. This aim spawned a debate which clearly highlighted two specific needs: firstly, to regulate and supervise the sector, and secondly, to attract foreign banks.

\section{The macroeconomic environment}

Unlike events in the preceding decade, the macroeconomic climate of the 1990s was one of accelerating growth, which fostered a rapid expansion of shortterm lending to consumers and firms. Capital-market liberalization, at a time of abundant liquidity in the international financial market, attracted foreign capital inflows, thereby removing the traditional external constraint on the expansion of demand and imports. This facilitated low-inflation growth, particularly in countries that had adopted stabilization programmes based on an exchange-rate anchor, combined with rapid commercial opening. In this situation, the banks faced strong demand for short-term credit and were able to expand their operations merely by accommodating it. In the second place, the international scenario allowed all banks, local and foreign alike, to increase their external financing. This phenomenon is related to more stable exchange rates and the development of the international derivatives market, which enabled financial investors to partially hedge exchange-rate risk and uncertainty.

\section{From changes in financial regulation and supervision to the entry of international banks}

A major obstacle to development of the financial system in Latin American countries, and particularly for attracting foreign banks, was the absence of appropriate institutions for regulation and supervision - a key 
element for the development of market infrastructure. This shortcoming had discouraged foreign banks from engaging in credit transactions with local consumers or firms. Laws on guarantees were inefficient or nonexistent, for example, and legal rulings could be indefinitely postponed and arbitrarily overturned once adopted. Anglo-Saxon law, commonly followed in the international financial market, was unknown in the region, and in general there were no legal precedents, which made the outcome of litigation unpredictable. Given that the development of certain segments of the financial system generally requires long-term contracts, regulatory shortcomings prevented such development - and in many cases still prevent it - by leaving foreign banks permanently exposed to the risk of contracts being breached. This undermined their competitive advantages because, in the absence of appropriate legislation, information management and knowledge of potential clients and the authorities become particularly important, and local institutions clearly held the advantage in these domains.

The reforms to financial regulation formally or informally removed the entry barriers facing foreign banks, thanks to which they began to move into the region and gain an increasingly large market share (table 2). Three vehicles were used in this process: privatizations, mergers and acquisitions, together with greenfield investments driven by the expansion needs of individual corporations. As a result, within a few years foreign banking institutions were owners of over half of the region's largest banks as measured by assets. Another change stemming from the openingup policy was the acceptance of greater concentration in the banking industry, with the number of banks decreasing as a result of privatizations, mergers and acquisitions. As shown in table 3, this phenomenon has not been exclusive to the region, since Asia and to a lesser degree Central Europe have experienced a similar trend, albeit with certain differences. Whereas concentration has generally declined in Asia and Central Europe, in Latin America the market shares of the three largest and 10 largest banks have increased, with numerous smaller firms disappearing altogether.

\begin{tabular}{lccccc} 
TABLE 2 & $\begin{array}{l}\text { Latin America (seven countries): Foreign } \\
\text { banks' share of banking assets in the } \\
\text { Region, 1990-2001 } \\
\text { (Percentages) }\end{array}$ \\
& 1990 & 1994 & 1999 & 2000 & 2001 \\
\hline Argentina & 10 & 18 & 49 & 49 & 61 \\
Brazil & 6 & 8 & 17 & 23 & 49 \\
Chile & 19 & 16 & 54 & 54 & 62 \\
Colombia & 8 & 6 & 18 & 26 & 34 \\
Mexico & 0 & 1 & 19 & 24 & 90 \\
Peru & 4 & 7 & 33 & 40 & 61 \\
Venezuela & 1 & 1 & 42 & 42 & 59
\end{tabular}

Source: Prepared by the authors on the basis of IMF (2000), BIS (2001b) and Salomon Smith Barney (2001).

\begin{tabular}{|c|c|c|c|c|c|c|}
\hline \multirow[b]{3}{*}{ Country } & \multicolumn{6}{|c|}{$\begin{array}{l}\text { Latin America, Asia and Central Europe: Indicators of concentration in the banking } \\
\text { sector, 1994-2000 } \\
\text { (Share of total deposits) }\end{array}$} \\
\hline & \multicolumn{3}{|c|}{1994} & \multicolumn{3}{|c|}{2000} \\
\hline & $\begin{array}{l}\text { Number } \\
\text { of banks }\end{array}$ & $\begin{array}{c}\text { Three largest } \\
\text { banks (\%) }\end{array}$ & $\begin{array}{l}\text { Ten largest } \\
\text { banks (\%) }\end{array}$ & $\begin{array}{l}\text { Number } \\
\text { of banks }\end{array}$ & $\begin{array}{c}\text { Three largest } \\
\text { banks }(\%)\end{array}$ & $\begin{array}{l}\text { Ten largest } \\
\text { banks (\%) }\end{array}$ \\
\hline \multicolumn{7}{|l|}{ Latin America } \\
\hline Argentina & 206 & 39.1 & 73.1 & 113 & 39.8 & 80.7 \\
\hline Brazil & 245 & 49.9 & 78.8 & 193 & 55.2 & 85.6 \\
\hline Chile & 37 & 39.5 & 79.1 & 29 & 39.5 & 82.0 \\
\hline Mexico & 36 & 48.3 & 80.8 & 23 & 56.3 & 94.5 \\
\hline Venezuela & 43 & 43.9 & 78.6 & 42 & 46.7 & 75.7 \\
\hline \multicolumn{7}{|l|}{ Asia } \\
\hline Republic of Korea & 30 & 52.8 & 86.9 & 13 & 43.5 & 77.7 \\
\hline Malaysia & 25 & 44.7 & 78.3 & 10 & 43.4 & 82.2 \\
\hline Philippines & 41 & 39.0 & 80.3 & 27 & 39.6 & 73.3 \\
\hline Thailand & 15 & 47.5 & 83.5 & 13 & 41.7 & 79.4 \\
\hline \multicolumn{7}{|l|}{ Central Europe } \\
\hline Czech Republic & 55 & 72.0 & 97.0 & 42 & 69.7 & 90.3 \\
\hline Hungary & 40 & 57.9 & 84.7 & 39 & 51.5 & 80.7 \\
\hline Poland & 82 & 52.8 & 86.7 & 77 & 43.5 & 77.7 \\
\hline Turkey & 72 & 40.7 & 79.1 & 79 & 35.9 & 72.0 \\
\hline
\end{tabular}

Source: Stallings and Studart (2001) and IMF (2001, p. 11). 


\section{The environment in which foreign banks entered the region in the 1990s}

Unlike the pattern in industrialized countries, the financial sector in Latin America continues to be dominated by banks, with little development of other types of financial institutions. Nonetheless, significant changes have occurred in recent years. Firstly, markets have become broader and deeper. This occurred partly as a result of the spectacular reduction in inflation rates throughout the region - price increases today are in single digits, compared to three and even four digits in the 1980s. As a result, families and firms are now more willing to hold money and other financial assets, thereby providing the basic requirements for development of the financial system. The stronger institutional framework obtained from regulation and financial supervision reduces the risks run by individual agents. In terms of market deepening, the ratio of money supply (M2) to GDP increased significantly in several countries in Latin America during 1992-2000 (ECLAC, 2003). Some diversification has also taken place in the capital market, in response to multiple causes: increased capital flows up to 1998; privatization of social security; and the deregulation of institutional investors, which led to increased investment in securitized instruments and generated a virtuous circle in several of the region's economies (ECLAC, 2003).

\section{II}

\section{Foreign banks: microeconomic efficiency versus macroeconomic effectiveness}

This section analyses the impact that foreign banks have had on microeconomic efficiency and macroeconomic effectiveness, particularly in terms of solving the problems that have traditionally afflicted the Latin American financial system. This obviously has consequences for the financial constraints facing firms and the stability of the regional banking system. The microeconomic indicators presented here are not very different from those used in other studies, since they compare the performance of foreign and local banks in terms of profitability, efficiency and liquidity. To simplify, we refer to this as the microeconomic efficiency of the banking system. Despite their limitations, these indicators are normally used to evaluate the way in which banks are operating, and their degree of risk exposure. The counterpart at the aggregate level would be macroeconomic effectiveness. To study this aspect, we analyse access to credit by the productive sector and families, together with the corresponding interest rates and spreads, and the contribution made by the banking system to stability.

As is true of most economic analysis, the step from micro- to macroeconomic performance is not a direct one. Nonetheless, some of the results presented below suggest that the microeconomic efficiency of the regional banking system increased during the 1990s, thanks partly to the role played by foreign banks. In the macroeconomic domain, however, cost of and access to credit and stability all failed to improve. This section attempts to explain this paradox.

\section{Microeconomic efficiency}

Three indicators in particular can be used to compare the performance of banking institutions: profitability, efficiency and liquidity. Given that the foreign banks only gained a strong presence in Latin America in the late 1990s, the analysis considers the period 1997 2001. The data cover the 20 largest institutions in terms of total assets in the countries where international banks were mainly concentrated: Argentina, Brazil, Chile, Colombia, Mexico, Peru and Venezuela. The 20 largest banks generally encompass over $80 \%$ of the system.

When evaluating microeconomic performance, it must be remembered that the local banking system has faced strong competition from foreign banks in their drive to gain market share. This has certainly forced the local players, especially the larger ones, to become more efficient. On this point, it is interesting to consider not only the average performance trend for the two groups, but also the deviation from the mean, since this 
can be used as an indicator of the capacity of small entities to incorporate new technologies and raise their performance in a more competitive environment.

\section{a) Indicators of profitability}

Taking Latin America as a whole, there are no statistically significant differences in profitability between local and foreign banks ${ }^{2}$ (table 4), whether measured as the return on assets or as the return on equity. A similar analysis for each individual country confirms this result. After acquiring local institutions, foreign banks took a series of measures, which will undoubtedly enhance efficiency and profitability in the future, although possibly raising costs in the short run. In strategic terms, these banks are just beginning to move out of a positioning phase towards one of increasing profitability.

Additional confirmation of the scant difference in profitability between local and foreign banks, whether measured in relation to assets or with respect to capital, is the similarity of their period-to-period trends, which display a very high correlation -0.74 on average for the entire set of countries. ${ }^{3}$ Nonetheless, variance analysis reveals less dispersion among foreign banks than in local ones: profitability varies more among local institutions than among their foreign competitors, as is verified by the available statistics, especially in Argentina, Chile and Mexico. This is probably because local banks are considerably more heterogeneous than their foreign counterparts in terms of size, liquidity, target markets and managerial and technological structures.

\begin{tabular}{|c|c|c|c|c|c|c|c|c|c|c|c|c|}
\hline \multirow{4}{*}{ Country } & \multicolumn{12}{|c|}{$\begin{array}{l}\text { Latin America (seven countries): indicators of the profitability of local and } \\
\text { foreign banks, 1997-2001 }\end{array}$} \\
\hline & \multicolumn{6}{|c|}{ Return on assets } & \multicolumn{6}{|c|}{ Return on equity } \\
\hline & \multicolumn{3}{|c|}{ Local banks } & \multicolumn{3}{|c|}{ Foreign banks } & \multicolumn{3}{|c|}{ Local banks } & \multicolumn{3}{|c|}{ Foreign banks } \\
\hline & $1997-2001$ & 1997 & 2001 & $1997-2001$ & 1997 & 2001 & 1997-2001 & 1997 & 2001 & 1997-2001 & 1997 & 2001 \\
\hline Argentina & 0.79 & 0.33 & 1.78 & 0.30 & -0.72 & 0.29 & 3.06 & 2.49 & 5.87 & 6.03 & 2.13 & 7.43 \\
\hline Brazil & 0.90 & 1.04 & 0.49 & 0.71 & 0.20 & 0.60 & 12.30 & 13.08 & 5.26 & 8.47 & 0.23 & 7.17 \\
\hline Chile & 0.81 & 1.85 & 0.99 & 0.57 & 0.38 & 0.72 & 13.11 & 12.38 & 15.82 & 10.45 & 6.34 & 14.17 \\
\hline Colombia & -0.11 & 1.33 & 1.03 & -0.63 & -0.11 & 0.15 & 7.43 & 8.18 & 9.79 & 1.35 & -2.65 & 0.15 \\
\hline Mexico & 1.16 & 0.60 & 2.45 & 1.21 & 1.09 & 1.82 & 6.88 & 0.48 & 9.36 & 11.20 & 7.64 & 19.29 \\
\hline Peru & 0.76 & 0.70 & 1.18 & 0.37 & -0.20 & 0.21 & 7.77 & 10.63 & 6.86 & 4.48 & 0.29 & 3.70 \\
\hline Venezuela & 2.20 & 2.19 & 2.20 & 1.92 & 2.11 & n.a. & 14.94 & 20.66 & 2.56 & 16.24 & 15.74 & . \\
\hline
\end{tabular}

Source: Prepared by the authors on the basis of Latin Banking Guide \& Directory (2002).

TABLE 5

Latin america (seven countries): indicators of the efficiency of local and foreign banks, 1997-2001

\begin{tabular}{|c|c|c|c|c|c|c|c|c|c|c|c|c|}
\hline \multirow[t]{3}{*}{ Country } & \multicolumn{6}{|c|}{ Overdue loans/gross loans } & \multicolumn{6}{|c|}{ Operating expenses/total income } \\
\hline & \multicolumn{3}{|c|}{ Local banks } & \multicolumn{3}{|c|}{ Foreign banks } & \multicolumn{3}{|c|}{ Local banks } & \multicolumn{3}{|c|}{ Foreign banks } \\
\hline & $1997-2001$ & 1997 & 2001 & $1997-2001$ & 1997 & 2001 & $1997-2001$ & 1997 & 2001 & $1997-2001$ & 11997 & 2001 \\
\hline Argentina & 10.86 & 13.01 & $12.06^{\mathrm{a}}$ & 5.92 & 5.80 & 6.01 & 79.91 & 102.1 & 21.9 & 85.13 & 163.9 & 19.06 \\
\hline Brazil & 10.29 & 5.84 & 14.13 & 4.68 & 1.91 & 7.37 & 79.74 & 84.4 & 76.3 & 93.10 & 115.9 & 67.2 \\
\hline Chile & 1.58 & 0.97 & 1.82 & 1.03 & 0.37 & 1.31 & 82.80 & 77.9 & 69.8 & 65.03 & 63.7 & 62.9 \\
\hline Colombia & 8.01 & 5.54 & 3.96 & 6.10 & 4.91 & 3.69 & 102.79 & 82.1 & 64.6 & 125.29 & 92.4 & 74.5 \\
\hline Mexico & 6.17 & 6.21 & 6.43 & 1.96 & 1.48 & 2.09 & 108.59 & 102.4 & 73.2 & 90.27 & 86.0 & 63.7 \\
\hline Peru & 6.78 & 4.61 & 7.70 & 6.43 & 4.91 & 6.36 & 91.67 & 83.7 & 78.2 & 114.78 & 106.4 & 84.9 \\
\hline Venezuela & 7.02 & 3.42 & 12.15 & 6.59 & 2.05 & . & 73.86 & 65.3 & 70.9 & 75.26 & 72.0 & . \\
\hline
\end{tabular}

Source: Prepared by the authors on the basis of Latin Banking Guide \& Directory (2002).

a 2000 .

2 This is measured by the probability of overlap between the confidence intervals of the means. The confidence interval considers the standard deviation with respect to the mean of each group, thereby taking into account in the comparison not only the mean value, but also its dispersion (see table A.1 of the Appendix).
3 The correlation is very low for Argentina, however, and negative in the case of Peru. Brazil, Chile, Colombia, Mexico and Venezuela register correlations that range between 0.46 and 0.92 


\section{b) Indicators of efficiency}

The analysis in this case is based on two indicators normally used by banking regulators: i) operating expenses in relation to total income; and ii) overdue loans as a percentage of the total loan portfolio. The first of these indicators measures operating efficiency, while the second is a fairly crude approximation to the quality of risk management (table 5). Analysis of the data reveals an interesting initial result, namely a general improvement in the operational efficiency of local banks during the period studied. In six of the seven countries, both foreign and local banks significantly reduced their ratio of operating expenses to total expenditure. ${ }^{4}$ Most of this efficiency improvement has occurred since 2000, which suggests that it may be linked to processes of operations rationalization, optimization of human resources, and the incorporation of new technologies and technological platforms that the banking industry is embarked upon. In Argentina, notwithstanding the financial crisis, efficiency improved continuously between 1997 and 2001 in local and foreign banks alike. In Brazil, on the other hand, the efficiency of local banks remained relative stable, before increasing slightly during 1999-2001, while the foreign banks registered a more substantial improvement. In Colombia, Mexico and Peru, efficiency trended steadily upwards from 1999 onwards in both types of banks.

Although in terms of overlapping confidence intervals there are no statistically significant differences in risk management between local and foreign banks, the coefficient is always lower among the latter. Unlike their local counterparts, foreign banks maintained a relatively healthy loan portfolio on average throughout the period under analysis. This should not be surprising, because most foreign banks were embarked upon an aggressive policy of loan restructuring when they began activities in Latin America, as a key element of their positioning strategy in the region. The policies of SCH (Banco Santander Central Hispano) and BBVA (Banco Bilbao Vizcaya Argentaria) in Argentina, Brazil, Chile and Mexico are clear examples of this. Comparing data over time, however, the percentage of non-performing loans in the total portfolio of each country shows no sign of

4 In Chile, foreign banks have been much more efficient than their local counterparts. Nonetheless, competition in the market has forced local banks to cut costs, so this indicator has shown a persistent narrowing of the gap each year, to the point where the difference in 2001 was no longer statistically significant. decreasing. This is true for national and foreign banks alike, and is explained by the worsening macroeconomic situation in the region, which has resulted in many firms and families falling into payment arrears, despite the banks' efforts to improve risk management.

\section{c) Indicators of liquidity}

The liquidity indicator chosen here is the effective availability of loanable funds - understood as the difference between total credits and provisions for non-performing loans- over total deposits: thus, liquidity indicator $=($ total credits - provisions $) /$ total deposits

The larger this difference, the greater is the risk being incurred by the bank; and, conversely, the smaller the difference the more cautious is its strategy. This is because the variation in loans reflects the bank's level of indebtedness; but a larger provision against non-performing loans indicates either that the bank is subject to more stringent regulatory constraints or simply that it expects loan recovery to be more difficult.

The liquidity situation differs across countries (table 6 and figure A.1 of the appendix). In Brazil, for example, foreign banks were more liquid than local ones throughout the period, and increasingly so in 2000 and 2001; but at the same time, the liquidity of foreign banks in Brazil is the most heterogeneous of the region. Thus, while liquidity is higher on average among foreign banks than among local ones, the dispersion is so great that it is hard to draw aggregate conclusions, which therefore weakens the initial argument. The opposite is true of Chile and Mexico, since local banks have a liquidity index that is both higher and more stable (smaller standard deviation).

Another interesting phenomenon is the sharp drop in liquidity registered among foreign banks following the Asian and Russian crises. In Argentina this indicator declined steadily from 1997 to 2001 for all types of banks, with no major differences between local and foreign players. Given that, in general, all banks have seen their loan portfolios deteriorate, it is hardly surprising that they have adopted a more prudent policy. Rather than changes in ownership, this attitude seems to reflect a more uncertain economic climate, which leads us to the final point in the analysis, namely, the macroeconomic effectiveness of foreign banks in the region. 
Latin America (seven countries): Effective availability of loanable funds in relation to total deposits, as a liquidity indicator, 1997-2001

(Percentages)

\begin{tabular}{|c|c|c|c|c|c|c|}
\hline & \multicolumn{3}{|c|}{ Local banks } & \multicolumn{3}{|c|}{ Foreign banks } \\
\hline & $1997-2001$ & 1997 & 2001 & 1997-2001 & 1997 & 2001 \\
\hline Argentina $^{\mathrm{a}}$ & 84.5 & 97.0 & 90.9 & 91.9 & 93.9 & 82.1 \\
\hline Brazil & 95.2 & 102.1 & 71.9 & 201.5 & 163.8 & 167.3 \\
\hline Chile & 111.6 & 118.3 & 108.7 & 95.2 & 139.6 & 85.2 \\
\hline Colombia & 142.0 & 105.5 & 128.9 & 192.9 & 112.2 & 208.1 \\
\hline Mexico & 106.9 & 108.2 & 132.9 & 74.9 & 90.0 & 44.1 \\
\hline Peru & 134.0 & 113.2 & 118.2 & 130.2 & 165.7 & 95.4 \\
\hline Venezuela & 74.2 & 66.1 & 107.5 & 68.5 & 73.4 & $\ldots$ \\
\hline
\end{tabular}

Source: ECLAC, on the basis of Latin Banking Guide \& Directory (2002).

a In the case of Argentina, the figures are for 2000.

\section{Macroeconomic impact}

The microeconomic analysis shows that while foreign banks do not differ significantly from local ones in an operational sense, they do act much more prudently in assessing and managing risk, and they make significantly higher provisions against losses than local banks do. This is a genuine benefit for the region. Nonetheless, a microeconomically sounder banking system is not necessarily better, per se, for economic development. Greater macroeconomic effectiveness would be obtained only if foreign banks were indeed helping to improve (or mitigate) bad credit conditions -in other words, if they improved the existing supply, cost and maturity conditions of financing. Despite constraints arising from data availability and the period of analysis, the present section attempts to evaluate this.

\section{a) Foreign banks and the aggregate supply of credit}

The strengthening of international banks in Latin America in the late 1990 s coincided with a period that was particularly unfavourable for the expansion of banking activities, due to slower growth and the instability that followed in the wake of the Asian crisis. Powerful external shocks (financial problems and a loss of trade momentum), compounded by the corresponding domestic responses, nearly always resulted in monetary tightening. Given the wider spreads and higher capital costs that such policies usually entail, a vicious circle tends to be generated between credit and risk (because of greater insolvency), and the banks necessarily become more conservative. In some coun- tries, such as Argentina and Ecuador, the period was also characterized by banking crises.

It is no surprise, therefore, that in many Latin American countries the deepening process among private-sector banks (expansion of credit to broader sectors of the population) has stalled since 1997. As shown in figure 1 , which considers seven countries, the ratio of private credit to GDP was lower in 2001 than in 1998 everywhere except Chile; and in 1998 it was already far below the level prevailing in most other developing countries (let alone developed ones). Indeed, the credit standstill seems even more worrying in view of the average interest rates being charged on loans in those countries (see table 7), because part of the variation in loans consists of existing credit being renewed (rollovers). A situation where the rate of variation in loans is less than the average interest rate charged in the system could be an indication of effective contraction in the supply of credit; in other words, the volume being rolled over does not include the payment needed for debt service, so the effective availability of financing for expenditure is correspondingly less. In 2001, there were signs of this phenomenon in several countries of the region (ECLAC, 2002).

In some countries the situation is particularly alarming. In Mexico, for example, the real supply of credit has fallen almost continuously since the "tequila crisis" of 1994, dropping from $35 \%$ of GDP in that year to about $10 \%$ in 2001 , as the banks have been engaged in an ongoing process of writing off the large number of impaired loans. In that country, a substantial proportion of the financing of domestic activity consists of supplier credits and foreign loans. Moreover, the restructuring of the banking system led to a vigorous entry of foreign banks (see box 2), as a 
result of which Mexico has recently become the country with greatest foreign participation in the region. Even so, given the negative impact of the retrenchment in the United States economy, bank credit is not showing signs of recovery.

The situation in Argentina was highly unsatisfactory even before the upheaval of 2001. Lending began to stall in the period between the Asian and Russian crises, and the situation worsened during the ensuing years. Between 2000 and 2001, lending fell by nearly

FIGURE 1

Latin America: Ratio of credit to GDP, 1991-2001

(Percentages)

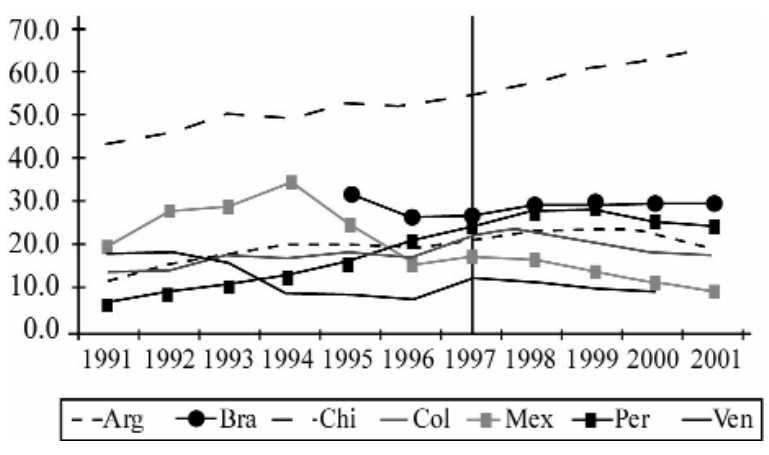

Source: ECLAC, on the basis of IMF (2002).
$18 \%$, and the system collapsed completely following the ending of the convertibility regime and the implementation of the freeze on bank deposits known as the "corralito". In general, the credit standstill is directly related to a more cautious attitude among the banks, especially foreign ones. If one considers the portfolio distribution of the banks in the region, the credit crunch is not surprising: in three countries (Argentina, Brazil and Chile), there was a reduction in the share of loans in total bank assets, local and foreign alike, reflecting the fact that banks sought lower-risk assets, such as government bonds. In Mexico and Colombia, loans declined in relation to total assets in local banks, but not in the case of their foreign counterparts.

\begin{tabular}{|c|c|c|c|c|c|}
\hline & \multicolumn{5}{|c|}{$\begin{array}{l}\text { Latin America: Variation in lending to the } \\
\text { private sector in constant } 1998 \text { values and } \\
\text { real interest rates, 1997-2001 } \\
\text { (Percentages) }\end{array}$} \\
\hline & \multicolumn{2}{|c|}{ Real variation in credit } & \multicolumn{3}{|c|}{ Real interest rates on loans } \\
\hline & $1997-2000$ & $2000-2001$ & 1997-2000 & 2000 & 2001 \\
\hline Argentina & 1.4 & -17.6 & 11.0 & 12.7 & 27.0 \\
\hline Brazil & 11.4 & 14.4 & 66.6 & 48.1 & 46.4 \\
\hline Chile & 6.8 & 9.1 & 11.0 & 9.7 & 9.5 \\
\hline Colombia & -1.5 & 12.9 & 16.1 & 9.5 & 12.4 \\
\hline Mexico & -4.2 & -7.5 & 9.6 & 9.4 & 8.6 \\
\hline Peru & 4.2 & -2.6 & 23.8 & 23.2 & 21.4 \\
\hline Venezuela & 0.2 & 26.4 & 6.1 & 11.2 & 9.0 \\
\hline
\end{tabular}

Source: ECLAC, on the basis of IMF (2002). 
Box 2

FOREIGN BANKS DOMINATE THE MEXICAN BANKING SYSTEM, BUT CREDIT FAILS TO RECOVER

The Mexican banking sector was reprivatized in the early 1990s, in a process involving Mexican shareholders. As the legislation of that time did not allow more than $20 \%$ foreign ownership of banks, international financial corporations chose to maintain a presence exclusively through representation offices. The new owners of the banks came from the management of Mexican stock market firms; their experience in lending and risk analysis was virtually non-existent. This, compounded by regulation and supervision shortcomings, magnified the financial crisis and economic recession that befell the country in late 1994 and 1995. The need to recapitalize the banking system, together with the signing of the NAFTA agreement, provoked major institutional changes in the Mexican financial system, including the removal of obstacles to the entry of foreign banks. By signing up to NAFTA, Mexico had undertaken to open up the financial sector to international competition (albeit in different ways for different intermediaries), and this meant participation by foreign capital in local banking institutions. The process occurred in two stages; until 1998 foreign ownership of a bank's equity was limited to $50 \%$; but thereafter the limit was completely lifted, thereby fully liberalizing the sector.

Opening-up occurred as part of a general restructuring of the banking sector, which had been severely weakened by the "tequila crisis" and by a massive non-performing portfolio. To promote capitalization of the banking sector, the State took over the non-performing portfolio amounting to some US\$ 120 billion. This was managed by the Bank Savings Protection Fund (FOBAPROA), which subsequently became the Bank Savings Protection Institute (IPAB). The fund was recognized as public debt guaranteed by the State, on which the latter paid interest of the order of $40 \%$ per year until late 2000 - firstly to local banks and then to foreign ones. The sale of local banks to foreign banking institutions involved large volumes of foreign exchange. In 2000, BBVA paid US\$ 1.75 billion to acquire Bancomer. Its rival, BSCH, purchased Serfin for US\$ 1.56 billion in 2001, and Citigroup paid US\$ 12.5 billion for Banco Nacional de México (BANAMEX). The final entrant, HSBC Holdings, paid US\$ 1.14 billion in August 2002 for the Bital financial group, the fourth-largest player in the Mexican financial system. As these monies went straight into the hands of the banks' former shareholders, the process did nothing to reduce the bank debt which the State had had to assume in order to bail out the system.

Foreign banks have also had access to cheaper funds than those mentioned above, but this did not result in credit expansion or lower costs for Mexican firms. The fact that domestic banks have been acquired by foreign institutions has not altered their oligopoly status or risk-aversion, and they continue mainly to live off high yields obtained on risk-free assets, such as public bonds. This means that their rent-seeking relationship with the State has not changed. Bank profits grew rapidly following their acquisition by foreign institutions (see figure 2). Although the yield on public bonds has fallen sharply (in 2002 it dropped below 10\%), instead of lending to firms or families, the banks have raised their service commissions to shore up their profitability. This partly explains why credit has ground to a standstill in Mexico: the change of ownership in the private bank sector has not stimulated greater competition, and banks have accommodated their strategy to portfolio-allocation and risk-evaluation practices that discourage lending. The recession of recent years, compounded by doubts that bankruptcy legislation would be effectively enforced, have been powerful motives for banks not to alter their behaviour.

Source: Prepared by the authors. 
FIGURE 2

Mexico: Net income of the banking system, 1997-2001

(Millions of dollars)

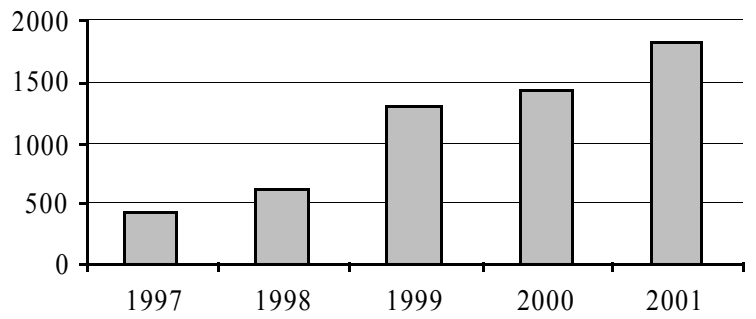

Source: Prepared by the authors on the basis of Latin Finance (2002) and Latin Banking Guide \& Directory (2002).

\section{b) Spreads and the cost of credit}

With regard to bank intermediation, although spreads actually narrowed between 1997 and 2001 in nearly all the Latin American countries, spreads have remained large, resulting in average interest rates that are far above inernational levels. In Brazil, for example, spreads remain above 30\%, with lending rates over $45 \%$, despite the central bank having implemented an explicit policy since 1999 to reduce spreads through lower compulsory reserve requirements and measures to increase competitiveness and transparency, among others. Despite the significant increase in foreign-bank participation in the region, only two of the seven countries analyzed (Chile and Venezuela) had spreads no larger than $6 \%$ in 2001; but even this was far above the averages in OECD and Asian countries.

Except for Brazil, there are no figures that distinguish foreign and local banks in terms of spread, although the signs are that they are quite similar. In Brazil, spreads among local and foreign banks are not only very similar, but they also follow the same time trend. Although the increase in spreads is a reaction to higher risk stemming from macroeconomic instability, this is unrelated to the increase in overdue loans or in the reserves made by the banks. As shown in table 9, in at least three countries (Brazil, Chile and Venezuela) local banks made smaller provisions against the non-performing portfolio in 2001 than the average for the period 1997-2001; the same is true of foreign banks in Brazil and Chile. To summarize, the entry of foreign banks has not had a very significant effect on the cost of capital, since this responds more to the macroeconomic climate than to differences in cost management, for local and foreign players alike. Foreign banks seem to be adapting to the regional reality rather than imposing their own dynamic on the determination of capital costs.

TABLE 8

Latin America (15 countries): Bank intermediation spreads, 1997-2001

\begin{tabular}{|c|c|c|c|c|c|c|}
\hline \multirow[t]{2}{*}{ Country } & \multicolumn{2}{|c|}{ Deposit rates } & \multicolumn{2}{|c|}{ Spreads } & \multicolumn{2}{|c|}{ Lending rates } \\
\hline & 1997 & 2002 & 1997 & 2002 & 1997 & 2002 \\
\hline Argentina & 7.0 & 40.9 & 2.1 & 10.8 & 9.2 & 56.2 \\
\hline Bolivia & 14.7 & 9.3 & 30.8 & 10.5 & 50.1 & 20.8 \\
\hline Brazil & 24.4 & 18.6 & 43.3 & 36.2 & 78.2 & 61.5 \\
\hline Chile & 12.0 & 3.9 & 3.3 & 3.8 & 15.7 & 7.9 \\
\hline Colombia & 24.1 & 9.2 & 8.1 & 6.8 & 34.2 & 16.5 \\
\hline Costa Rica & 13.0 & 11.3 & 8.4 & 13.5 & 22.5 & 26.3 \\
\hline Ecuador & 28.1 & 5.4 & 11.7 & 9.2 & 43.0 & 15.1 \\
\hline Guatemala & 5.8 & 7.0 & 12.1 & 9.3 & 18.6 & 16.9 \\
\hline Honduras & 21.3 & 14.1 & 8.9 & 7.7 & 32.1 & 22.9 \\
\hline Mexico & 14.7 & 2.9 & 8.6 & 6.3 & 24.5 & 9.3 \\
\hline Panama & 7.0 & 5.0 & 3.4 & 5.2 & 10.6 & 10.5 \\
\hline Paraguay & 13.0 & 22.5 & 13.1 & 9.4 & 27.8 & 34.0 \\
\hline Peru & 15.0 & 4.1 & 13.0 & 10.2 & 30.0 & 14.7 \\
\hline Uruguay & 19.6 & 33.5 & 43.4 & 64.9 & 71.6 & 120.1 \\
\hline Venezuela & 14.7 & 29.3 & 7.8 & 5.9 & 23.7 & 36.9 \\
\hline Simple average Latin America & 15.6 & 14.5 & 14.5 & 14.0 & 32.8 & 31.3 \\
\hline Weighted average L. America & 18.6 & 14.6 & 21.6 & 18.4 & 45.0 & 36.3 \\
\hline Simple average OECD ${ }^{\mathrm{a}}$ & & 0.1 & & 3.7 & & 3.8 \\
\hline Simple average Asia ${ }^{\mathrm{b}}$ & & 1.9 & & 3.5 & & 5.4 \\
\hline
\end{tabular}

Source: Prepared by the authors on the basis of IMF (2002).

a Sample includes Germany, Italy, Japan, Netherlands, Spain, Switzerland and the United States.

${ }^{\mathrm{b}}$ Sample consists of Indonesia, South Korea, Malaysia, Philippines, Singapore and Thailand. 
TABLE 9

Latin America: Ratio between provisions for doubtful loans and non-performing loans, 1997-2001

\begin{tabular}{lccccccc}
\hline & \multicolumn{3}{c}{ Local banks } & & \multicolumn{3}{c}{ Foreign banks } \\
\cline { 2 - 4 } \cline { 7 - 8 } & $1997-2001$ & 1997 & 2001 & & $1997-2001$ & 1997 & 2001 \\
\hline Argentina & 2.68 & 0.72 & 4.22 & & 1.90 & 0.75 & 5.13 \\
Brazil & 1.43 & 1.67 & 0.74 & & 1.58 & 1.83 & 0.62 \\
Chile & 2.14 & 2.71 & 1.76 & & 2.69 & 2.85 & 1.57 \\
Colombia & 0.78 & 0.48 & 2.05 & & 0.98 & 0.54 & 1.84 \\
Mexico & 1.84 & 1.27 & 2.75 & & 2.47 & 1.00 & 1.59 \\
Peru & 1.18 & 1.37 & 1.42 & & 1.21 & 1.01 & 1.43 \\
Venezuela & 1.67 & 2.45 & 1.39 & & 1.82 & 2.03 & $\ldots$ \\
\hline
\end{tabular}

Source: Prepared by the authors on the basis of IMF (2002).

\section{c) Stability of the banking sector}

To evaluate the impact of foreign banks on the macroeconomic effectiveness of regional banking systems, a different criterion is useful, namely stability. Before the arrival of foreign banks, much was said about their likely beneficial effect in terms of making the system less fragile. At least three arguments were deployed: i) foreign banks would have more sophisticated risk-management systems, based on more rigorous supervision by the authorities in their countries of origin; ii) they would be less vulnerable to the region's domestic cycles, because their effective exposure to them would be relatively small in relation to their broad global diversification; and iii) local subsidiaries of foreign banks would always be able to rely on their parent companies in the event of abrupt swings in liquidity.

Considering only indicators of risk management and provision against losses, clearly the foreign banks must have contributed to a sounder banking system. Nonetheless, as Stallings and Studart (2001) indicate, the violent macroeconomic shocks of recent years rendered even the most sophisticated monitoring and riskmanagement systems ineffective. In fact, in highly unstable macroeconomic situations, such systems may even aggravate risk, given their well-known pro-cyclical properties. ${ }^{5}$ Accordingly, it is not surprising that foreign banks, which in general have more sophisticated (and more conservative) risk evaluation systems than

\footnotetext{
5 As Borio, Farfine and Lowe (2001) show, the pro-cyclical nature of the banking system, stems from the fact that most risk evaluation systems work with a horizon that is too short to accurately determine default risks and correctly value the financial and real assets used as collateral. Accordingly, at times of economic retrenchment, risk indicators tend to rise very sharply, while the values of the assets posted in guarantee decline. As a result of these two movements, the banking system as a whole tends to behave more
}

their local counterparts, end up reacting to economic cycles in a much more accentuated fashion.

As regards the argument that the global diversification of foreign banks has positive effects on stability, the other side of the coin is that these banks are much more sensitive than local ones to expectation shocks originating in the advanced economies. For that reason, just as international banks have reduced their exposure to the region's economies (BIS, 2001a), their local subsidiaries have adopted an increasingly cautious stance.

Lastly, in response to the argument that foreign banks can count on unconditional support from their parent companies at times of liquidity loss, two comments need to be made. Firstly, the possibility of supporting their subsidiaries is compromised by the fact that the parent company has to maintain in its country of origin a level of capital compatible with the weighted risk of its assets. This is because episodes of financial crisis in an emerging country are usually reflected in its "country-risk" rating, and any contribution from the parent company has to represent an expansion of its global capital. As seen recently in the Argentine crisis, this places severe restrictions on the ability of parent companies to supply funds at times of major macroeconomic uncertainty and/or liquidity crisis in emerging economies. Secondly, there are provisions in financialsystem regulations that prohibit supporting the liquidity of an ailing subsidiary under certain circumstances. For example, legislation in the United States ${ }^{6}$ establishes that a bank is not obliged to pay deposits made in a subsidiary abroad, if it is unable to do so because: a) a state of war, insurrection or civil revolt exists; or b) because it is prevented by an action or instrument of the government of the host country, undertaken without explicit written agreement with the bank. This law was added to the existing legislation in 1994, after Citibank was taken to court by depositors in the Philippines and Vietnam and lost the respective cases.

In short, the macroeconomic effectiveness of the banking system is profoundly damaged by the current macroeconomic climate, which is extremely unfavourable for banking activity. This climate generates a more cautious attitude on the part of the banks, which in turn leads to a credit standstill, maintenance of

cautiously, leading to a credit contraction (or slowdown in its growth), which, in turn, ends up generating a vicious circle. As the macroeconomy becomes more volatile, credit risk is evaluated more cautiously, which intensifies the pro-cyclical nature of the system. 6 See section 25C of the Federal Reserve Act (section 326 of the Riegle-Neal Interstate Banking and Branching Efficiency Act, codified in 12 U.S Code section 633). 
very large spreads and a shortening of loan maturities. In order to avoid greater losses arising from macroeconomic instability in the region (especially in countries that suffered currency crises

\section{III \\ Conclusions}

The major presence of international banks in Latin America during the 1990s partly reflected their strategy of seeking markets throughout the world, and partly reflected changes in the economic climate and institutional context in the region. Regional penetration has produced costs and benefits, both for banking investors and for the financial systems concerned. In terms of benefits, until 2001 when the Argentine crisis broke out, foreign banks grew on a sustained basis, gaining a significant share of domestic banking systems, ranging from $34 \%$ in Colombia to $90 \%$ in Mexico in 2001. A decade earlier, Chile had been the country with greatest foreign participation, but this accounted for less than $20 \%$ of the market at that time. In addition, the profitability of foreign banks' activities in the region was growing, whether measured by the return on assets or the return on equity; in some cases it exceeded the bank's overall rate of return. At the same time, the foreign banks were expanding their participation in the capital market, especially in pension-fund management, one of the most attractive businesses for financial institutions.

The costs arose from various sources, including the region's instability and its vulnerability to external shocks and currency crises; in many cases foreign banks also underestimated the local competition (Brazil is a good example of this). The Argentine crisis clearly marked the turning point in their expansion strategy, although the cost of this crisis depended on the importance of Latin America and particularly Argentina in the bank's global business. At one extreme are the Spanish banks, whose interests in the region represented between $26 \%$ and $29 \%$ of their total assets. At the other are banks that only expanded in the treasury management or corporate banking segments. In the middle is Citigroup, whose global diversification prevented it from being seriously affected by the deterioration in regional conditions, notwithstanding its by no means negligible interests in the region (7\% of total assets). similar to that in Argentina), foreign banks adopt a more conservative stance, which entails maintaining high liquidity and therefore relatively low lending levels.
The analysis also shows that while foreign banks do not differ significantly from local ones in terms of operating efficiency, they do act more cautiously in the evaluation and management of risk. Nonetheless, the fact that there is no statistically significant efficiency difference between local and foreign banks does not mean they have not had a positive impact in the region. Clearly, the competition generated by the entry of foreign banks has galvanized efforts by local banks to cut costs and enhance profitability, in order to protect themselves from being driven out of the market. In fact, despite the oligopolistic nature of the industry, competition nowadays between large local banks and foreign ones is very strong. The interesting thing about the financial sector is that all competitors have access to state-of-the-art technology. As this is relatively cheap, it is not exclusive to foreign banks, thanks to progress made in information and communication technology, which the financial system uses particularly intensively. Nonetheless, with few exceptions -Chile being one- the cost reduction generated by technological progress has not been passed on in the form of cheaper financial services either for firms or for individuals. Worse still, it has also failed to improve access to credit for firms.

Accordingly, the positive outcome for the region in terms of microeconomic efficiency stands in contrast to the macroeconomic impact (the effectiveness of foreign-bank participation in the system), as measured by the conditions under which credit is extended, the availability of business financing, and the stability of the system. The analysis leads to the conclusion that foreign banks have not had a significant effect at this level: they are more cautious than their local counterparts when extending credit, and their response to crises is clearly pro-cyclical, all of which intensifies the effects of monetary tightening. Despite management efficiency, interest-rate spreads only narrowed in four of the seven countries analyzed, and even in those they remained extremely high - way above rates in 
Asia, not to mention those in OECD countries. Spreads have reacted more to the macroeconomic environment than to differences in cost management, and foreign banks seem to be adapting to the national reality in this respect, rather than imposing their own dynamic on the cost of capital.

Lastly, in terms of reaction to systemic crises, the experience of recent years has shown that the behaviour of transnational corporations towards their subsidiaries and branches depends on a number of factors: the institutional framework in the corporation's country of origin; the institutional framework in the host country; and steps taken by the local authorities during the crises. In practice, the parent companies of international banks cannot be considered lenders of last resort; their behaviour at times of crisis has depended on the nature of the problems the banks were facing in the host country and the type of establishment in question. 


\section{Appendix}

FIGURE A.1

Latin America (6 countries): Trend of liquidity index in each country, by type of bank, 1997-2001
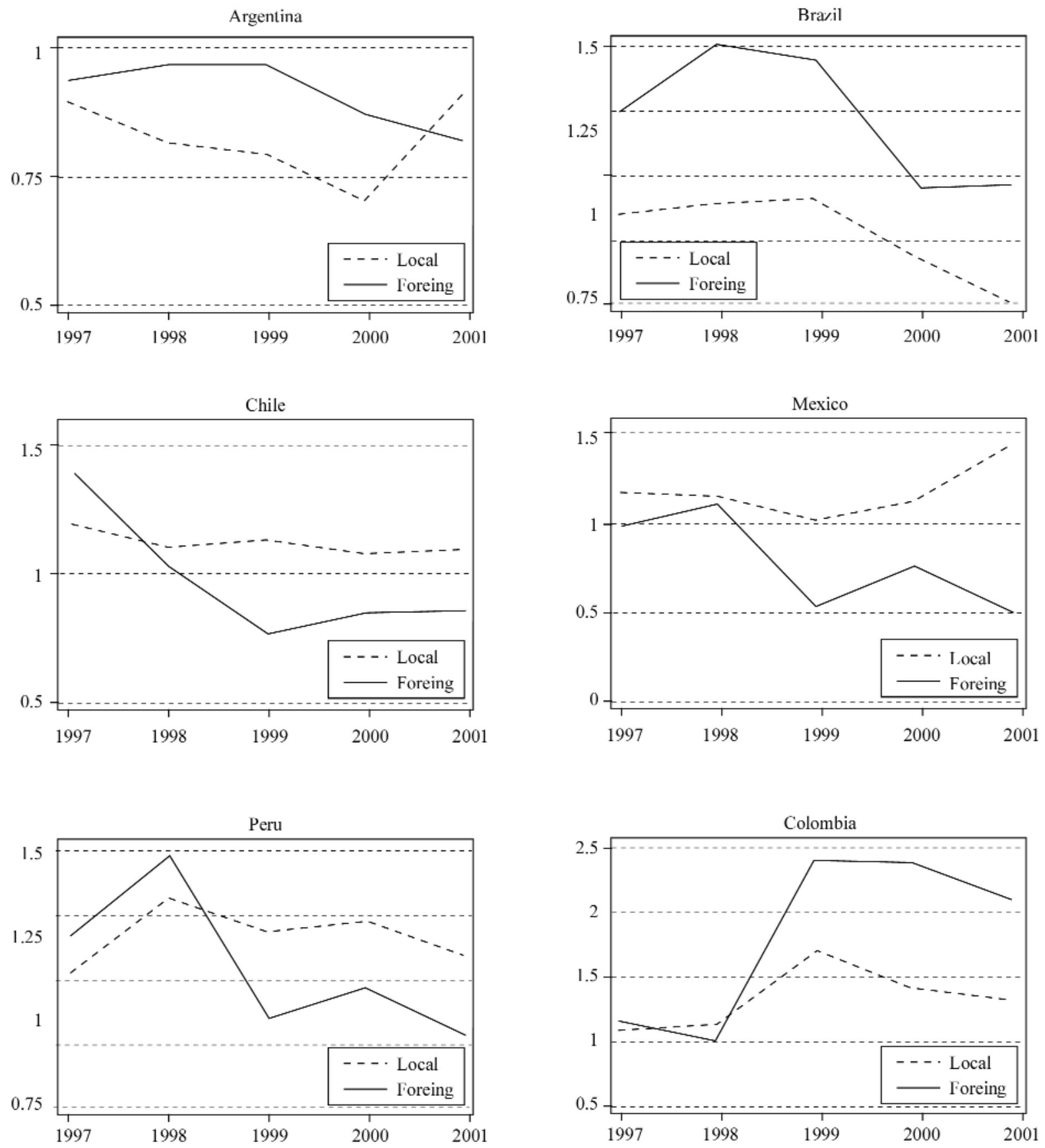

Source: Latin Finance (2002). 
TABLE A.1

Latin America (seven countries): Confidence in the region, by profitability indicators, $1997-2001^{\mathrm{a}}$

\begin{tabular}{lrrr}
\hline \multirow{2}{*}{ Country } & \multicolumn{2}{c}{ Return on assets } & \multicolumn{2}{c}{ Return on equity } \\
\cline { 2 - 3 } & Local banks & Foreign banks & Local banks \\
\hline Argentina & $0.25 \sim 1.32$ & $-0.16 \sim 0.77$ & $-2.35 \sim 8.48$ \\
Brazil & $0.57 \sim 1.23$ & $0.44 \sim 0.98$ & $9.52 \sim 15.07$ \\
Chile & $0.64 \sim 0.98$ & $0.45 \sim 0.68$ & $10.55 \sim 15.67$ \\
Colombia & $-1.02 \sim 0.78$ & $-0.57 \sim 0.75$ & $3.95 \sim 10.91$ \\
Mexico & $0.48 \sim 1.83$ & $0.78 \sim 1.64$ & $3.62 \sim 13 \sim 10.32$ \\
Peru & $0.34 \sim 1.17$ & $0.13 \sim 0.90$ & $5.39 \sim 10.1$ \\
Venezuela & $1.65 \sim 2.74$ & $1.77 \sim 2.97$ & 12.74 \\
\hline
\end{tabular}

Source: ECLAC, on the basis of Latin Banking Guide \& Directory (2002).

a $95 \%$ of confidence.

TABLE A.2

Latin America (seven countries): Confidence in the region, by efficiency indicators, $1997-2001^{a}$

\begin{tabular}{|c|c|c|c|c|}
\hline \multirow[t]{2}{*}{ Country } & \multicolumn{2}{|c|}{ Overdue loans /Gross loans } & \multicolumn{2}{|c|}{ Operation expenses/Total income } \\
\hline & Local banks & Foreign banks & Local banks & Foreign banks \\
\hline Argentina & $63.1 \sim 96.1$ & $66.7 \sim 103.4$ & $8.2 \sim 13.3$ & $4.6 \sim 7.2$ \\
\hline Brazil & $75.4 \sim 85.0$ & $75.6 \sim 110.8$ & $7.1 \sim 13.4$ & $3.3 \sim 6.0$ \\
\hline Chile & $74.4 \sim 91.1$ & $57.0 \sim 73.0$ & $1.2 \sim 1.9$ & $0.7 \sim 1.2$ \\
\hline Colombia & $87.4 \sim 118.1$ & $82.2 \sim 140.3$ & $6.3 \sim$ & $4.6 \sim 7.6$ \\
\hline Mexico & $80.8 \sim 136.3$ & $79.6 \sim 101.4$ & $4.6 \sim$ & $0.9 \sim 2.9$ \\
\hline Peru & $87.0 \sim 96.2$ & $84.6 \sim 110.1$ & $5.5 \sim$ & $5.3 \sim 7.3$ \\
\hline Venezuela & $70.0 \sim 77.6$ & $69.9 \sim 80.5$ & $4.5 \sim$ & $3.1 \sim 5.4$ \\
\hline
\end{tabular}

Source: ECLAC, on the basis of Latin Banking Guide \& Directory (2002).

a $95 \%$ of confidence.

BIS (Bank for International Settlements) (2001a): Cycles and the financial systems, BIS Annual Report, Basel.

(2001b): The Banking Industry in the Emerging Market Economies: Competition, Consolidation and Systemic Stability, BIS Papers, No. 4, Basel.

Borio, C., C. Farfine and P. Lowe (2001): Procyclicality of the Financial System and Financial Stability: Issues and Policy Options, BIS Papers, No. 1, Basel.

ECLAC (Economic Commission for Latin America and the Caribbean) (1995): Reformas económicas en América Latina: una síntesis de la experiencia en once países, LC/R.1606, Santiago, Chile.

(1996): Strengthening Development. The Interplay of Macro- and Microeconoomics, "Libros de la CEPAL" series, No. 42, LC/G.1898-P, Santiago, Chile, July. United Nations publication, Sales No. E.96.II.G.2.

(2002): Foreign Investment in Latin America and the Caribbean. 2001 Report, LC/G.2178-P, Santiago, Chile, October. United Nations publication, Sales No. E.02.II.G.47. (2003): Foreign Investment in Latin America and the Caribbean. 2002 Report, LC/G.2198-P, Santiago, Chile, April. United Nations publication, Sales No. E.03.II.G.11.
Held, G. and L.F. Jiménez (2001): Liberalización financiera, crisis y reforma del sistema bancario chileno: 1974-1999, in R. French-Davis and B. Stallings (eds.), Reformas, crecimiento y políticas sociales en Chile desde 1973, Santiago, Chile, ECLAC/LOM Ediciones.

IMF (International Monetary Fund) (2000): International Capital Markets: Developments, Prospects, and Key Policy Issues, Washington, D.C.

(2001): International Capital Markets: Develop-ments, Prospects, and Key Policy Issues, Washington, D.C. (2002): International Financial Statistics, Washington, D.C., June.

Latin Banking Guide \& Directory (2002): http: www.latinfinance. com, August.

Latin Finance (2002): http://www.latinfinance.com, September.

Salomon Smith Barney (2001): Foreign Financial Institutions in Latin America. 2001 Update, New York, December.

Stallings, B. and R. Studart (2001): Financial Regulation and Supervision in Emerging Markets: The Experience of Latin America since the Tequila Crisis, WIDER Discussion Paper, No. 2002/45, Helsinki, United Nations University. 